\title{
HuKuman Bagi PELAKU TINDAK PIDANA Penadahan Dengan Sistem GadaI
}

\author{
Arassy Wardani, \\ NurLailatul Musyafa'ah \\ wardani_arassy@yahoo.co.id \\ UIN Sunan Ampel Surabaya Jl. A. Yani \\ 117 Surabaya
}

\begin{abstract}
This study aims to investigate crime of fencing by the lien system contained in decision No. 293/Pid.B/2013/PN. Mkt. In his decision, judge used Article 480 Paragraph 1 (one) about the aggravating factors, the mitigating circumstances, witnesses at the trial, and the evidences in the trial as a consideration in deciding the case of fencing. In this case, judge decided that the defendant or criminal fencing system is sentenced to prison for 6 (six) months, from the demand of 10 (ten) months. According to the review of Islamic criminal law, the Judge's ruling has been in accordance with Islamic law, because the defendant's act is categorized as jarîmah and is sentenced with ta'zîr. That is because the criminal act is an offense where its punishment is not regulated in al-Qur'an and al-Hadith. Keywords: Crime of fencing, pawn system, Islamic criminal law
\end{abstract}

Abstrak: Penelitian ini bertujuan untuk meneliti tindak pidana penadahan dengan sistem gadai yang terdapat dalam putusan No.293/Pid.B/2013/PN. Mkt. Dalam putusan tersebut, Majelis Hakim menggunakan Pasal 480 ayat 1, hal-hal yang memberatkan, hal-hal yang meringankan, saksi-saksi di persidangan, serta bukti-bukti dalam persidangan sebagai pertimbangan dalam memutus perkara tindak penadahan ini. Dalam kasus ini, Majelis Hakim memutus bahwa terdakwa atau pelaku tindak pidana penadahan dengan sistem gadai dijatuhi pidana penjara selama 6 (enam) bulan, dari tuntutan 10 (sepuluh) bulan. Menurut tinjauanf figh jinâyah putusan hakim telah sesuai dengan hukum Islam, karena perbuatan terdakwa termasuk dalam jarîmah yang hukumannya adalah ta'zîr. Hal tersebut dikarenakan tindak pidana tersebut merupakan sebuah pelanggaran yang hukumannya tidak diatur dalam Nash.

Kata Kunci: Tindak pidana penadahan, sistem gadai, fiqh jinâyah 


\section{Pendahuluan}

Dengan perkembangan dunia yang semakin kompleks dewasa ini, maka tidak jarang pula menimbulkan berbagai permasalahan serius yang perlu mendapatkan perhatian sedini mungkin. Kejahatan dalam bentuk pencurian terhadap harta benda tidak akan tumbuh subur apabila tidak ada yang menampung hasil curian itu, benda-benda curian itu tidak mungkin untuk selalu dimiliki dan disimpan sendiri, maka di sinilah peranan seorang penadah hasil pencurian terhadap harta benda sangat diperlukan. ${ }^{1}$

Adanya penadah sebagai penampung kejahatan pencurian memberikan kemudahan bagi si pelaku untuk memperoleh keuntungan, sehingga pelaku pencurian tidak harus menjual sendiri hasil curiannya ke konsumen tetapi dapat ia salurkan melalui penadah yang berkedok sebagai pedagang di pasar loak. Permasalahan yang timbul itu, baik berupa pelanggaran terhadap tata krama kehidupan bermasyarakat maupun aturan-aturan hukum, menciptakan suatu fenomena yang bertentangan dengan kaidah moral dan kaidah susila serta aturan-aturan hukum. ${ }^{2}$

Pelanggaran yang terjadi itu adalah merupakan realitas daripada keberadaan manusia yang tidak bisa menerima aturan-aturan itu secara keseluruhan. Kalau hal semacam itu terus dibiarkan berlarut-larut dan kurang mendapat perhatian, maka akan dapat menimbulkan keresahan dalam masyarakat sehingga dapat mengganggu ketertiban umum.

Salah satu jenis pelanggaran yang biasa terjadi dalam masyarakat, baik yang bertentangan dengan kaidah moral, etika dan agama terlebih lagi terhadap peraturan hukum yang tertuang dalam KUHP adalah delik penadahan. Penadahan sebagai kejahatan, sekaligus merupakan salah satu gejala sosial yang tumbuh dan berkembang dalam masyarakat.

Dalam Kitab Undang-Undang Hukum Pidana (KUHP) Indonesia, delik penadahan digolongkan sebagai kejahatan terhadap harta benda yang diatur dalam Pasal 480, 481 dan Pasal 482 KUHP. ${ }^{3}$

\footnotetext{
${ }^{1}$ Lamintang, Delik-Delik Khusus Kejahatan terhadap Harta Kekayaan (Jakarta: Sinar Grafika, 2009), 130.

${ }^{2}$ Ibid., 132.

${ }^{3}$ Moeljatno, Kitab Undang-Undang Hukum Pidana (Jakarta: Bumi Aksara, 2012), 172.
} 
Pengadilan Negeri Mojokerto, telah banyak menyidangkan kasus dan memberi hukuman kepada para pelaku tindak pidana. Salah satu tindak pidana yang telah disidangkan adalah tindak pidana penadahan yang dilakukan oleh warga Mojokerto.

Berdasarkan uraian tersebut di atas, bahwa salah satu penyebab meningkatnya kejahatan penadahan yang terjadi di Kota Mojokerto adalah karena kurangnya kesadaran hukum, kurangnya pengetahuan masyarakat akan hukum, serta kurang tegasnya pengawasan para aparat penegak hukum. ${ }^{4}$

Dalam KUHP Indonesia penadahan berdasarkan pasal 480 digabung antara delik sengaja (mengetahui) barang itu berasal dari kejahatan dan delik kelalaian (culpa), ditandai dengan kata-kata "patut dapat mengetahui” barang itu berasal dari kejahatan. Ini disebut delik pro parte doleus pro parte culpa (separuh sengaja dan separuh kelalaian). Dalam hal ini penadah dapat memperkirakan bahwa barang yang dibeli, ditukar dan seterusnya itu berasal dari hasil kejahatan karena harganya terlalu murah.

Tindak pidana penadahan disebut tindak pidana pemudahan yakni karena perbuatan menadah telah mendorong orang lain untuk melakukan kejahatan-kejahatan yang mungkin saja tidak akan dilakukan, seandainya tidak ada orang yang bersedia menerima hasil kejahatannya. ${ }^{5}$ Akan tetapi, pengaturan tindak pidana penadahan di dalam Bab II KUHP sebagai tindak pidana pemudahan itu sebenarnya kurang tepat, sebab perbuatan menadah yang didorong oleh hasrat untuk memperoleh keuntungan sebenarnya tidak dapat disebut sebagaimana yang telah dilakukan dengan maksud untuk memudahkan orang lain melakukan kejahatan.

Jika jenis-jenis perbuatan yang dewasa ini dipandang sebagai tindak pidana penadahan memang perlu untuk tetap dilarang di dalam KUHP yang baru, maka apa salahnya jika perbuatan-perbuatan tersebut diatur dalam suatu bab tertentu yang mengatur masalah tindak pidana penadahan. ${ }^{6}$ Tindak pidana penadahan dalam bentuk pokok oleh pembentuk undang-undang telah diatur dalam Pasal 480 KUHP, yang rumusan aslinya di dalam bahasa Belanda berbunyi sebagai berikut:

\footnotetext{
${ }^{4}$ Andi Hamzah, Delik-delik tertentu di dalam KUHP(Jakarta : Sinar Grafika, 2009), 131.

${ }^{5}$ lbid, 132.

${ }^{6}$ Lamintang, Delik-Delik Khusus Kejahatan Terhadap Harta Kekayaan..., 363.
} 
Met gevangenisstraf van ten hoogste vier jaren of geldboete van ten hoogste negen hondret gulden wordt gestraft:

1. Als schhuldig aan heling, hij die eenig voorwerp waarvan hijweet of redelijikerwijs moet vermoeden, dat het door misdrijf is verkregen koopt, huurt, inruilt, in pand neemt, als geschenk aanneemt, of uit winsbejag verkoopt,verhuurt, verruilt, in pand geeft, vervoet, bewaart of verbergt;

2. Hij die uit de opbrengst van eenig voowerp waarvan hij weet of redelijkerwijs moet vermoeden dat het door misdrijf is verkregen, voordeel trekt?

Artinya:

Dipidana dengan pidana penjara selama-lamanya empat tahun atau dengan pidana denda setinggi-tingginya Sembilan Ratus Rupiah:

1. Karena bersalah telah melakukan penadahan yakni barangsiapa membeli, menyewa, menukar, menerima gadai, menerima sebagai hadiah atau dengan harapan akan memperoleh keuntungan, menjual, menyewakan, menukarkan, menggadaikan, mengangkut, menyimpan, atau menyembunyikan suatu benda yang ia ketahui atau secara patut harus dapat ia duga bahwa benda tersebut telah diperoleh karena kejahatan.

2. Barangsiapa mengambil keuntungan dari hasil suatu benda yang ia ketahui atau secara patut harus dapat ia duga bahwa benda tersebut telah diperoleh karena kejahatan. ${ }^{8}$

Tindak pidana penadahan seperti yang dimaksud dalam Pasal 480 angka 1 KUHP terdiri atas:

a. Unsur-unsur subjektif :

1. Yang ia ketahui atau waarvan hij weet;

2. Yang secara patut harus dapat ia duga atau waarvan hij edelij kerwijs moet vermoeden;

b. Unsur-unsur objektif :

1. kopen atau membeli

2. buren atau menyewa

3. inruilen atau menukar

4. in pand nemen atau menggadai

\footnotetext{
${ }^{7}$ Ibid., 363.
}

${ }^{8} \mathrm{Ibid},{ }^{7}, 363$. 
5. als geschenk aannemen atau menerima sebagai hadiah atau sebagai pemberian

6. uit winstbejag atau didorong oleh maksud untuk memperoleh keuntungan

7. verkopen atau menjual

8. verhuren atau menyewakan

9. in pand geven atau menggadaikan

10. vervoen atau mengangkut

11. bewaren, atau menyimpang dan

12. verbergen atau menyembunyikan'

Dalam praktik yang biasanya dapat dianggap terbukti adalah unsur culpa, yaitu bahwa si pelaku penadahan dapat dianggap patut harus dapat menyangka asalnya barang dari kejahatan. Unsur yang termuat dalam Pasal 480 ke-2 yang mengenai hal bahwa suatu barang yang secara langsung diperoleh dengan pencurian atau penggelapan dan sebagainya sudah dijual atau ditukarkan dengan lain barang atau uang curian yang sudah dipergunakan untuk membeli barang. Maka barang siapa mengambil untung dari uang atau barang yang menggantikan barang-barang yang langsung diperoleh dengan kejahatan itu melakukan tindak pidana dari Pasal 480 ke-2 tersebut. Misalnya, seorang yang mendapat bagian dari uang hasil penjualan barang yang dicuri atau digelapkan dan sebagainya. Perbuatan si penadah berjenis dua, yakni:

1. Yang menerima dalam tangannya yaitu membeli, menyewakan, menukari, menerima gadai, menerima sebagai hadiah.

2. Yang melepaskan barang dari tangannya yaitu menjual, menyewakan, menukarkan, menggadaikan, memberikan sebagai hadiah, ditambah dengan mengangkut, menyimpan, dan menyembunyikan.

Bagi perbuatan ke-2 ditambah unsur maksud untuk mendapat untung (winstbejag) penambahan ini tidak diadakan pada perbuatan ke1 tadi. Perbuatan itu dapat dikatakan bahwa maksud untuk mendapat untung merupakan unsur dari semua penadahan. Karena sudah jelas bahwa untuk melakukan tindak pidana penadahan seperti yang dimaksud dalam Pasal 480 angka 1 KUHP itu, undang-undang telah mensyaratkan keharusan adanya unsur kesengajaan itu meliputi semua unsur tindak pidana yang terletak di belakangnya.

\footnotetext{
9 Ibid., 365.
} 
Dalam Putusan No.293/Pid.B/2013/PN Mojokerto dijelaskan bahwasanya saudara terdakwa, awalnya tidak mengetahui ternyata barang (mobil xenia) yang digadaikan oleh saudara Penatas kepada terdakwa adalah barang hasil curian. Barang ini oleh saudara Penatas diakui sebagai barang miliknya yang dia beli tetapi belum lunas. Setelah saudara terdakwa mulai merasa bahwa barang yang digadaikan kepada saudara terdakwa adalah

barang curian, maka saudara terdakwa pun menyembunyikan identitas barang tersebut dengan mengganti plat nopol palsu yang sudah terdakwa pesan.

Dalam kasus tersebut terdakwa kurang mengerti akan hukum, sehingga terdakwa mau menerima gadai tanpa mempertanyakan asal usul barang yang digadaikan kepada terdakwa. Dalam kasus di atas juga dapat diketahui bahwasanya kasus tersebut termasuk dalam tindak pidana penadahan yang mana didalamnya terdapat salah satu unsur-unsur penadahan yaitu "menerima sebagai gadai". ${ }^{10}$

Menurut bahasa, mencuri (sariqah) adalah mengambil sesuatu yang bukan miliknya secara sembunyi-sembunyi. Adapun menurut istilah adalah mengambil harta yang terjaga dan mengeluarkan dari tempat penyimpanannya tanpa ada kerancuan (shubhat) di dalamnya dan dilakukan secara sembunyi-sembunyi.

Adapun unsur-unsur pencurian dibagi menjadi empat, yaitu:

1. pengambilan harta secara diam-diam.

2. barang diambil itu berupa harta.

3. harta tersebut milik orang lain.

4. adanya niat yang melawan hukum ${ }^{11}$

Mencuri adalah mengambil harta milik orang lain dengan tanpa hak untuk dimilikinya tanpa sepengetahuan pemiliknya. Dasar sanksi hukum bagi pencuri dalam Al-Quran Allah swt telah berfirman:

"Laki-laki yang mencuri dan perempuan yang mencuri, potonglah tangan keduanya (sebagai) pembalasan bagi apa yang mereka kerjakan dan sebagai siksaan dari Allah. dan Allah Maha Perkasa lagi Maha Bijaksana" (Al-Ma'idah 38). ${ }^{12}$

Sedangkan pencurian dalam syariat Islam ada dua macam, yaitu sebagai berikut:

\footnotetext{
${ }^{10}$ Direktori Putusan Mahkamah Agung Republik Indonesia, Putusan No.293/Pid.B/2013/PN.Mkt, 2.

${ }^{11}$ A. Djazuli, Figh Jinayah (Jakarta: Raja Grafindo Persada, 1997), 73.

${ }^{12}$ M. Quraish Shihab, al-Qur'an dan Maknanya (Tanggerang: Lentera Hati, 2010), 114.
} 


\section{Pencurian yang hukumannya had}

2. Pencurian yang hukumannya ta'zîr

Pencurian yang hukumannya had terbagi menjadi dua bagian, yaitu: Pencurian ringan dan pencurian berat

Pencurian ringan menurut rumusan yang dikemukakan Abdul Qadir adalah mengambil harta milik orang lain dengan cara diam-diam, yaitu dengan jalan sembunyi-sembunyi. ${ }^{13}$ Sedangkan pengertian pencurian berat adalah mengambil harta milik orang lain dengan cara kekerasan.

Jarîmah hudûd sering diartikan sebagai tindak pidana yang macam dan sanksinya telah ditetapkan secara mutlak oleh Allah atau dalam al-Qur'an dan al-Sunnah (hudûd jamaknya had, artinya batas), hudûd merupakan kejahatan yang paling serius dan berat dalam hukum pidana Islam. Had adalah hukuman yang telah ditentukan dalam nas diganti dengan macam hukuman lain atau dibatalkan sama sekali oleh manusia. Alasan para fuqaha mengklasifikasikan jarîmah hudûd sebagai hak Allah. Pertama, karena perbuatan yang disebut secara rinci oleh alQur'an sangat mendatangkan kemaslahatan baik perorangan maupun kolektif. Kedua, jenis pidana dan sanksinya secara definitif disebut secara langsung oleh lafaz yang ada di dalam al-Qur'an sementara tindak pidana lainnya tidak. ${ }^{14}$

Kejahatan hudûd adalah kejahatan yang diancam dengan hukuman had yaitu hukuman yang ditentukan sebagai hak Allah. Kejahatan ini merupakan kejahatan yang paling berat dalam hukum pidana Islam.

Menurut etimologi al-rahn berarti al-thub $t$ wa al-dawâm yang artinya tetap dan kekal. Adapun menurut para ulama fiqh, al-rahn yakni :

1. Menurut Sayyid Sabiq, al-rahn adalah menjadikan barang berharga menurut pandangan shara' sebagai jaminan utang. ${ }^{15}$

2. Menurut Muhammad Rawwas Qal' ahji penyusun buku Ensiklopedi Fiqh berpendapat bahwa al-rahn adalah menguatkan utang dengan jaminan utang. ${ }^{16}$

3. Sedangkan menurut Nasrun Haroen, al-rahn adalah menjadikan suatu barang sebagai jaminan terhadap hak (piutang) yang mungkin

\footnotetext{
${ }^{13}$ Abd. al-Qadir Audah, al-Tashrî́ al-Jinâ'iy al-Islâmiy, juz II (Beirut: Dar al-Kitab al-Arabi), 514.

${ }^{14}$ Makhrus Munajat, Dekonstruksi Hukum Pidana Islam (Jogyakarta: Logung Pustaka, 2004), 95.

${ }^{15}$ Sayyid Sabiq, Fiqh Sunnah juz III (Bandung: PT. Al-Ma'arif, 1987), 153.

${ }^{16}$ Muhammad Rawas Qal'ahji, Ensiklopedi Fiqh (Jakarta: Raja Grafindo Persada, 1999), 463.
} 
dijadikan sebagai pembayaran hak (piutang) itu, baik keseluruhan ataupun sebagian. ${ }^{17}$

Sebagaimana telah didefinisikan oleh para ulama figh di atas, bahwa al-rahn adalah menjadikan barang berharga sebagai jaminan utang. Para ulama sepakat bahwa al-rahn diperbolehkan tetapi tidak diwajibkan, sebab gadai hanya bersifat jaminan saja jika kedua belah pihak tidak saling mempercayai. ${ }^{18}$

Ta'zîr secara etimologi berarti menolak atau mencegah. Sedangkan secara istilah ta'zîr diartikan sebagai suatu pelajaran atau pendidikan dalam bentuk hukuman tertentu. Hukuman tersebut bertujuan, mencegah yang bersangkutan mengulangi kembali perbuatannya dan membuat yang bersangkutan menjadi jera.

Sebagian ulama mengartikan ta'zîr sebagai hukuman yang berkaitan dengan pelanggaran, terhadap hak Allah dan hak hamba yang tidak ditentukan al-Qur'an dan Hadis. Ta'zîr berfungsi memberikan pengajaran kepada si terhukum dan sekaligus mencegahnya untuk tidak mengulangi perbuatan serupa. Sebagaian lain mengatakan sebagai sebuah hukuman terhadap perbuatan maksiat yang tidak dihukum dengan hukuman had atau kaffârat. ${ }^{19}$

Ta'zîr merupakan tindak pidana yang bentuk dan ancaman hukumnya ditentukan oleh penguasa sebagai pelajaran bagi pelakunya (ta'zîr artinya: ajaran atau pelajaran) sehingga dapat dikatakan bahwa hukum ta'zîr menjadi wewenang penguasa untuk menentukannya.

Ta'zîr adalah hukuman yang bersifat mendidik atas perbuatan dosa yang belum ditetapkan oleh shara' atau hukuman yang diserahkan kepada keputusan Hakim. Namun hukum ta'zîr juga dapat dikenakan atas kehendak masyarakat umum meskipun bukan perbuatan maksiat melainkan awalnya mubah. Dasar hukum ta'zîr adalah pertimbangan kemaslahatan dengan mengacu pada prinsip keadilan. Pelaksanaannya pun bisa berbeda tergantung pada tiap keadaan. Karena sifatnya yang mendidik maka bisa dikenakan pada anak kecil. Maka, jarîmah ta'zîr berbeda dengan jar mah hud $d$.

Jarîmah ta'zîr bisa dibagi menjadi tiga bagian yaitu:

1. Jarîmah ta’zîr karena melakukan perbuatan maksiat

\footnotetext{
17 Ibid., 463.

${ }^{18}$ Nasrun Haroen, Fiqh Muamalah (Jakarta: Gaya Media Pertama, 2000), 252.

${ }^{19}$ Rahmat Hakim, Hukum Pidana Islam (Figh Jinayah) (Bandung: Pustaka Setia, 2000) , 140-141.
} 
2. Jarîmah ta'zîr karena melakukan perbuatan yang membahayakan kepentingan umum

3. Jarîmah ta'zîr karena melakukan pelanggaran (mukhâlafah).

Sedangkan dilihat dari dari segi hak yang dilanggarnya, jarîmah ta'zîr dapat dibagi kepada dua bagian, yaitu:

1. Jarîmah ta'zîr yang berkaitan dengan hak Allah

2. Jarîmah ta'zîr yang berkaitan dengan hak perorangan (individu). ${ }^{20}$

Bentuk sanksi ta'zîr bisa beragam sesuai keputusan Hakim dan secara garis besar dapat dibedakan menjadi hukuman mati bisa dikenakan pada pelaku hukuman berat yang berulang-ulang, hukuman cambuk, hukuman penjara, hukuman pengasingan, menyita harta pelaku, mengubah bentuk barang, hukuman denda, peringatan keras, hukuman nasihat, hukuman celaan, pengucilan, pemecatan, dan publikasi.

Pengertian jarîmah sebagaimana dikemukakan oleh Imam alMawardi adalah sebagai berikut:

"Jarîmah adalah perbuatan-perbuatan yang dilarang oleh shara' yang diancam oleh Allah dengan hukuman had atau ta' ${ }^{\prime} \hat{i}{ }^{\prime 21}$

Ulama' fiqh membagi jarîmah itu menjadi tiga macam, yaitu jarîmah qisâs, jarîmah hudûd dan jarîmah ta'zîr. Sedangkan menurut alMawardi jarîmah itu dibagi menjadi dua macam, yaitu jarîmah had dan jarîmah ta'zîr. Kalau mengikuti sistem yang digunakan oleh al-Mawardi, jarîmah qisâs dan diyah sama-sama termasuk kelompok jarîmah hudûd, sebab ketentuan hukumnya sama-sama ditetapkan dalam nas. ${ }^{22}$

\section{Pengertian Pencurian (Sariqah)}

Pencurian adalah perbuatan mengambil harta atau benda berharga milik orang lain secara diam-diam dan memperoleh harta secara tidak halal atau haram serta merugikan orang lain karena mengambil harta orang lain secara sepihak. ${ }^{23}$ Seperti disebutkan dalam surat al-Nisa ayat 29:

Hai orang-orang yang beriman, janganlah kamu saling memakan harta sesamamu dengan jalan yang batil, kecuali dengan jalan

\footnotetext{
${ }^{20}$ A. Djazuli, Fiqh Jinayah..., 162.

${ }^{21}$ Ahmad Wardi, Muslich „, Hukum Pidana Islam (Jakarta: Sinar Grafika, 2005) , 1.

${ }^{22}$ Al-Mawardi, Hukum-Hukum Penyelenggaraan Negara dalam Syariat Islam (Jakarta: Darul-Falah, 2012), 129.

${ }^{23}$ Zainuddin Ali, Hukum Pidana Isalam (Jakarta: Sinar Grafika, 2012), 62.
} 
perniagaan yang berlaku dengan suka sama-suka di antara kamu.

Dan janganlah kamu membunuh dirimu; sesungguhnya Allah adalah Maha Penyayang kepadamu.

Unsur-unsur Pencurian (Sariqah):

1) subjek yakni barang siapa

2) Pengambilan yang dilakukan secara sembunyi-sembunyi.

3) Yang dicuri harus berupa harta kongkret dan dapat bergerak.

4) sehingga barang yang dicuri bisa dipindah-pindahkan, tersimpan oleh pemiliknya pada penyimpanan yang layak dan dianggap sebagai sesuatu yang berharga.

5) Harta yang dicuri adalah sesuatu yang berharga, setidaknya menurut versi pemiliknya.

6) Harta diambil (dicuri) pada waktu terjadinya pemindahan harta orang lain secara murni dan orang yang mengambilnya tidak memiliki hak kepemilikan sedikitpun terhadap harta tersebut.

7) Bersifat melawan hukum.

8) Terdapatnya unsur kesengajaan untuk memiliki barang tersebut atau iktikad jahat pelakunya. ${ }^{24}$

Jenis-jenis Pencurian:

1) pencurian ternak.

2) pencurian pada waktu ada kebakaran dan sebagainya.

3) pencurian pada waktu malam dalam sebuah rumah kediaman dan seterusnya.

4) pencurian oleh dua orang atau lebih bersama-sama, pencurian dengan jalan membongkar dan sebagainya.

5) pencurian dengan perkosaan, dan pencurian ringan. ${ }^{25}$

Berdasarkan atas pemahaman yang jelas tentang ayat al-Qur'an, mengenai sanksi terhadap sariqah (pencuri) yang terbukti melakukan pencurian dan tidak ditemukan sesuatu yang shubhat yang menghindarkannya dari hukuman, maka ulama sepakat bahwasanya sanksi terhadap pelaku pencurian adalah potong tangan.

\section{Pengertian Ta'zîr}

Ta'zîr merupakan salah satu bentuk hukuman yang diancamkan kepada pelaku tindak kejahatan yang dijelaskan dalam fiqh jinâyat. Ia

\footnotetext{
${ }^{24} \mathrm{Ibid}, 84$.

${ }^{25}$ Wirjono Prodjodikoro, Tindak-Tindak Pidana Tertentu di Indonesia..., 21.
} 
merupakan hukuman ketiga setelah hukuman qisâs-diyat dan hukuman hudûd. Makna Ta'zîr bisa juga diartikan mengagungkan dan membantu, seperti yang difirmankan Allah swt:

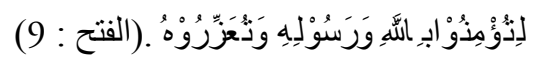

supaya kamu sekalian beriman kepada Allah dan Rasul-Nya, menguatkan (agama)Nya, membesarkan-Nya. Dan bertasbih kepada-Nya di waktu pagi dan petang.

Unsur-unsur Ta'zîr:

1) Nas (al-Qur'an dan hadis) yang melarang perbuatan dan mengancamkan hukuman terhadapnya, dan unsur ini biasanya disebut sebagai unsur formil (rukun shara).

2) Adanya tingkah laku yang membentuk jarîmah, baik berupa perbuatan-perbuatan nyata ataupun sikap tidak berbuat. Dan unsur ini biasanya disebut sebagai unsur materil.

3) Pelaku adalah orang mukallaf, yaitu orang yang dimintai pertanggung jawabannya atas perbuatan jarîmah tersebut. Dan unsur ini biasa disebut sebagai unsur moril. ${ }^{26}$

Sanksi Ta'zîr.

1) Sanksi ta'zîr yang berkaitan dengan badan. Adapun sanksi ta'zîr yang berkaitan dengan badan, dibedakan menjadi dua, yakni hukuman mati dan hukuman cambuk.

2) Sanksi ta'zîr yang berkaitan dengan kemerdekaan seseorang Mengenai hal ini, ada dua jenis hukuman yakni: hukuman penjara dan hukuman pengasingan.

3) Sanksi ta'zîr yang berkaitan dengan harta, sanksi ta'zîr dengan mengambil harta bukan berarti mengambil harta pelaku untuk diri hakim atau untuk kas Negara, melainkan menahannya untuk sementara waktu. Adapun jika pelaku tidak dapat diharapkan bertaubat, maka hakim dapat menyerahkan harta tersebut untuk kepentingan yang mengandung maslahat. ${ }^{27}$

\section{Pengertian Gadai (Rahn)}

Secara bahasa, rahn atau gadai berasal dari kata al-thubût yang berarti tetap dan al-dawâm yang berarti terus menerus. Sedangkan secara istilah dapat diartikan dengan menjadikan suatu benda berharga dalam

\footnotetext{
${ }^{26}$ A. Djazuli, Fiqh Jinayah,Cet. 2..., 161.

${ }^{27}$ Nurul Irfan, Mayrofah, Fiqh Jinayah, Cet. 1 (Jakarta: Amzah, 2013), 147.
} 
pandangan shara' sebagai jaminan atas adanya 2 kemungkinan, yakni untuk mengembalikan uang itu atau mengambil sebagian benda itu.

Syarat yang terkait dengan orang berakad (al-râhin dan almurtahin) adalah cakap bertindak hukum. Kecakapan bertindak hukum, menurut jumhur ulama adalah orang yang telah baligh dan berakal. Syarat yang terkait dengan sigat, ulama Hanafiyah berpendapat dalam akad al-rahn tidak boleh dikaitkan dengan syarat tertentu. Akan tetapi jumhur ulama berpendapat apabila syarat ini mendukung kelancaran akad, maka syarat ini diperbolehkan. Tetapi apabila syarat ini bertentangan dengan tabiat akad al-rahn, maka syaratnya batal. Syarat yang terkait dengan utang (al-marhûn bih). Syarat yang terkait dengan barang yang dijadikan jaminan (al-marhûn).

Sanksi dalam Islam gadai diperbolehkan asal bukan digunakan dalam kejahatan. Seperti dalam surat al-Baqarah ayat 282:

"Hai orang-orang yang beriman, apabila kamu bermu'amalah tidak secara tunai untuk waktu yang ditentukan, hendaklah kamu menuliskannya dan hendaklah seorang penulis di antara kamu menuliskannya dengan benar." (al-Baqarah : 282) 28 $^{28}$

\section{Kronologi Kasus Tindak Pidana Penadahan dengan Sistem Gadai di Mojokerto}

Pada hari jum'at tanggal 21 Desember 2012 sekitar pukul 12.00 Wib, Saudara Suwono al. Lutung Bin Giso yang bertempat di Jalan Raya Cokroaminoto Kel. Balongsari Kec. Magersari Kota Mojokerto. Saudara Penatas dan Saudara Feby al. Gendut mendatangi rumah saudara Suwono al. Lutung Bin Giso (terdakwa) untuk mengutarakan niatnya meminjam uang sebesar Rp. 25.000 .000 (dua puluh lima juta rupiah) dengan jaminan (gadai) mobil Xenia Nopol S-1273-QC dan mengatakan jika mobil tersebut dibeli sendiri seharga Rp. 130.000.000 (seratus tiga puluh juta rupiah). ${ }^{29}$

Saudara Penatas mengaku bahwa mobil yang ia beli tetapi uangnya masih kurang Rp. 20.000.000 (dua puluh juta rupiah), sehingga ia meminjam kepada saudara Suwono al. Lutung Bin Giso (terdakwa) yang tidak lain adalah kakak kandung saudara Penatas. Karena tergiur dengan jaminan yang diberikan oleh saudara Penatas maka saudara

\footnotetext{
${ }^{28}$ Kementrian Agama RI, al-Qur'an dan Tafsirnya, Jilid 1 (Jakarta: Widya Cahaya, 2011), 431.

${ }^{29}$ Enny RA Manurung, Wawancara, Mojokerto, 3 Juni 2014.
} 
Suwono al. Lutung Bin Giso (terdakwa) menerima jaminan (gadai) tanpa menanyakan BPKB mobil tersebut. Saudara Penatas berjanji akan menebus kembali mobil yang ia gadaikan kepada saudara Suwono al. Lutung Bin Giso (terdakwa) setelah 2

bulan peminjaman uang, kemudian saudara Suwono al. Lutung Bin Giso (terdakwa) memberikan uang Rp. 25.000.000 (dua puluh lima juta rupiah) tanpa disertai alat bukti pembayaran dan langsung dipotong Rp. 1.250.000 (satu juta dua ratus lima puluh ribu rupiah). Setelah uang diserahkan kepada saudara Penatas, mobil beserta STNK diserahkan kepada saudara Suwono al Lutung Bin Giso (terdakwa).

Pada tanggal 3 Januari 2013 saudara Penatas datang kembali menemui saudara Suwono al Lutung Bin Giso (terdakwa) untuk meminta tambahan uang gadai sebesar Rp. 5.000 .000 (lima juta rupiah). Satu minggu kemudian saudara Penatas kembali lagi kerumah saudara Suwono al Lutung Bin Giso (terdakwa) untuk meminta tambahan uang gadai sebesar Rp. 5.000 .000 (lima juta rupiah), sehingga total gadai pada dari mobil Xenia tersebut adalah sebesar Rp. 35.000.000 (tiga puluh lima juta rupiah).

Sekitar bulan Februari 2013 saudara Suwono al Lutung Bin Giso (terdakwa) mendatangi rumah saudara Penatas di Perum Alam Mojosari untuk menagih janji, akan tetapi saudara Penatas menjanjikan kembali kepada saudara Suwono al Lutung Bin Giso (terdakwa) akan menebus seminggu lagi. Setelah tiga kali ditagih akhirnya saudara Penatas tidak bisa dihubungi dan menghilang. Saat saudara Suwono al Lutung Bin Giso (terdakwa) mencari saudara Penatas di rumahnya, saudara Suwono al Lutung Bin Giso (terdakwa) diberitahu oleh petugas Pos Satpam Perumahan, bahwasanya mobil yang digunakan oleh saudara Suwono al Lutung Bin Giso (terdakwa) dicari oleh pemiliknya yakni orang Tarik Kab. Sidoarjo.

Pada hari Senin tanggal 1 April 2013 saudara Suwono al Lutung Bin Giso (terdakwa) memesan plat nomor palsu. Kemudian oleh saudara Suwono al Lutung Bin Giso (terdakwa) dipasang dimobil Xenia tersebut karena saudara Suwono al Lutung Bin Giso (terdakwa) merasa takut.

Pada hari Selasa tanggal 2 April 2013 sekitar jam 13.00 Wib, saudara Suwono al Lutung Bin Giso (terdakwa) didatangi petugas Kepolisian untuk dimintai keterangan, dan saudara Suwono al Lutung 
Bin Giso (terdakwa) mengakui jika mobil Xenia tersebut diperoleh dari saudara Penatas sebagai jaminan (gadai). ${ }^{30}$

Saksi Khumaidi, yang pada pokoknya memberikan keterangan sebagai berikut:

a) Bahwa saksi Khumaidi telah kehilangan mobil Daihatsu Xenia Nopol S-1273-QC Tahun 2011, warna hitam Noka MHKV1BA2JBK 104839 Nosim DH81999 atas nama Sudarsono beserta 1 (satu) lembar STNK yang merupakan milik adik saksi.

b) Bahwa saksi Khumaidi tidak tahu tentang keberadaan mobil xenia tersebut. Hanya saja saksi pernah mendengar bahwa mobil tersebut telah digadaikan berpindah-pindah tangan, namun saksi tidak tahu yang terakhir kali menerima gadai mobil tersebut. Ketika mobil xenia tersebut berhasil diamankan oleh pihak Kepolisian Polda Jawa Timur pada hari Selasa tanggal 2 April 2013.

c) Bahwa akibat dari hilangnya mobil xenia tersebut adik saksi mengalami kerugian kurang lebih sekitar Rp. 170.000.000,-.

d) Bahwa pada hari Jum'at tanggal 21 Desember, saudara Penatas dan Sudara Feby al Gendut mendatangi rumah saudara Suwono al Lutung Bin Giso (terdakwa) untuk mengutarakan niatnya yaitu untuk meminjam uang sebesar Rp. 25.000.000,-. Serta memberikan jaminan mobi xenia Nopol S-1273-QC. Terdakwa Suwono al Lutung tidak menanyakan BPKBnya karena saudara Penatas adalah saudara kandung terdakwa. Kemudian terdakwa memberikan uang Rp. 25.000.000,- dan langsung dipotong Rp. 1.250.000,-, dan uang tersebut diserahkan tanpa bukti pembayaran. Kemudian mobil xenia Nopol S-1273-QC tersebut ditinggal dirumah terdakwa beserta STNK.

e) Bahwa selanjutnya tanggal 3 Januari 2013, Saudara Penatas datang kembali ke rumah Suwono al Lutung Bin Giso (terdakwa) untuk minta tambahan uang gadai sebesar Rp. 5.000.000,-. Satu minggu kemudian saudara Penatas datang kembali ke rumah Suwono al Lutung Bin Giso (terdakwa) untuk meminta tambahan uang gadai sebesar Rp. 5.000.000,-, sehingga total gadai dari mobil tersebut adalah sebesar Rp. 35.000.000,-.

Bahwa kurang lebih sekitar bulan Februari 2013, Suwono al Lutung Bin Giso (terdakwa) datang ke rumah saudara Penatas di

\footnotetext{
${ }^{30}$ Direktori Putusan Mahkamah Agung Republik Indonesia, Putusan No.293/Pid.B/2013/PN Mkt, 2.
} 
Perum Alam Mojosari. Dan di sana terdakwa bertemu dengan saudara Penatas. Saat itu saudara Penatas berjanji seminggu lagi akan diambilnya atau ditebusnya. Setelah sampai tiga kali ditagih, akhirnya saudara Penatas tidak bisa dan menghilang.

g) Bahwa saat Suwono al Lutung Bin Giso (terdakwa) diberitahu petugas Pos Satpam Perumahan, jika mobil yang digunakan tersebut dicari oleh pemiliknya yaitu orang Tarik Kab. Sidoarjo. Sehingga pada hari Senin tanggal 1 April 2013 terdakwa memesan plat Nopol palsu, dikarenakan terdakwa merasa ketakutan. Pada hari Selasa tanggal 2 April 2013, sekitar pukul 13.00 Wib Suwono al Lutung Bin Giso (terdakwa) didatangi petugas Kepolisian untuk dimintai keterangan atas mobil yang digadaikan kepadanya.

Saksi Feby Ardhika Putra al Gendut, yang pada pokoknya memberikan keterangan sebagai berikut:

a. Bahwa saksi tidak kenal dan tidak ada hubungan keluarga maupun pekerjaan dengan terdakwa, namun saksi kenal dengan saudara kandungnya yang bernama Penatas.

b. Bahwa pada hari Jum'at tanggal 21 Desember 2012, saudara Penatas dan saksi mendatangi rumah terdakwa Suwono al Lutung Bin Giso. Kemudian saudara Penatas mengutarakan niatnya yaitu ingin meminjam uang sebesar Rp. 25.000.000,- dengan jaminan mobil xenia Nopol S-1273-QC. Terdakwa tidak menanyakan BPKBnya karena saudara Penatas adalah saudara kandung terdakwa. Kemudian terdakwa memberikan uang Rp. 25.000.000,- dan langsung dipotong Rp. 1.250.000,- tanpa disertai alat bukti pembayaran.

c. Bahwa saksi sudah tiga kali berhubungan dengan Penatas dalam hal gadai menggadai.

d. Bahwa tidak tahu siapa pemilik dari mobil xenia tersebut dan waktu digadaikan tanpa adanya BPKB hanya ada STNK saja.

e. Bahwa saksi tidak mengetahui dimana keberadaan Penatas sekarang.

\section{Hasil Wawancara}

Dari hasil wawancara ini, terdapat beberapa pendapat mengenai landasan yang digunakan oleh Majelis hakim dalam memutus perkara No. 293/Pid.B/2013/PN. Mojokerto. Antara lain:

a. Hakim Anggota 
1. Bahwasanya perbuatan terdakwa memenuhi unsur-unsur tindak pidana.

2. Bahwasanya perbuatan terdakwa memenuhi unsur-unsur dalam pasal 480 ayat 1 .

3. Mengenai hal-hal yang memberatkan.

4. Mengenai hal-hal yang meringankan.

5. Bahwa perkara ini dakwaanya ada dalam tindak pidana penadahan.

6. Bahwa dalam persidangan Jaksa Penuntut Umum harus dapat membuktikan bahwa terdakwa benar-benar bersalah. ${ }^{31}$

b. Panitera

1. Hakim selalu sah dan menyakinkan dalam memutus suatu perkara.

2. Melihat pasal 10 KUHP.

Sedangkan dalam hal hukuman atau sanksi yang dijatuhkan kepada terdakwa hakim melihat dari perkara itu sendiri, karena pada dasarnya setiap perkara tidak sama sanksinya walaupun perbuatannya sama. Dan hakim tidak boleh memberikan hukuman atau sanksi kepada terdakwa lebih dari enam tahun atau batas maksimal dari hukuman. Dalam memutus perkara Majelis hakim selalu melihat pada tiga hal, yakni: keadilan, kepastian hukum, dan kemanfaatan. Jika dalam menjalankan hukuman terdakwa

mendapatkan remisi, dan remisi merupakan kewenangan LP bukan kewenangan hakim. Tugas seorang hakim hanya sampai pada putusan saja.

\section{Landasan dan Pertimbangan Hukum yang Digunakan oleh Hakim Pengadilan Negeri Mojokerto}

Pertimbangan hukum adalah bagian dari putusan pengadilan yang mempertimbangkan dasar hukum yang dipakai dalam memutuskan suatu perkara, obyek studi yang saya teliti adalah kasus penadahan, di mana kasus penadahan ini merupakan kejahatan yang melanggar undang-undang dalam Pasal 480 (1) KUHP. Berdasarkan hal tersebut, diharapkan dari penelitian ini bertujuan untuk mengetahui seberapa jauh tindakan yang dilakukan oleh para penegak hukum. Dalam hal ini adalah pihak polisi, apakah benar-benar sudah melakukan pencegahan tindak pidana penadahan. Karena pihak polisi diharapkan memberikan penyadaran bagi masyarakat bahwa tindak pidana penadahan merupakan

${ }^{31}$ Wahyudi Said, Wawancara, Mojokerto, 3 Juni 2014. 
suatu kejahatan dan perbuatan tersebut adalah perbuatan yang melanggar hukum.

Dalam memutus setiap perkara majelis hakim selalu memiliki pertimbangan dan landasan yang mendasarinya. Salah satu pertimbangan yang digunakan oleh Majelis Hakim dalam memutus perkara yakni halhal yang memberatkan, hal-hal yang meringankan, serta Undang-undang dalam KUHP. Landasan yang digunakan oleh Majelis Hakim dalam memutus perkara No.293/Pid.B/2013/Pengadilan Negeri Mojokerto meliputi:

1. Majelis Hakim berpendapat bahwa terdakwa telah melakukan tindak pidana.

2. Bahwa perkara ini dakwaannya ada dalam unsur-unsur Pasal 480 ayat 1 KUHP.

Perbuatan terdakwa memenuhi unsur-unsur dalam KUHP Pasal 480 ayat 1 , yakni bahwasanya saudara Suwono al Lutung Bin Giso (terdakwa) telah terbukti melakukan tindak pidana penadahan yang telah dirumuskan dalam pasal 480 ayat 1 KUHP, dengan unsurunsur diantaranya:

a. Barang siapa, setiap orang atau siapa yang dalam hal ini adalah subyek hukum. Yang bertindak sebagai pelaku perbuatan yang secara hukum dilarang dan secara hukumharuslah cakap dan mampu untuk mempertanggung jawabkan perbuatan pidana tersebut.

b. Unsur membeli, menyewa, menukar, menerima sebagai gadai, menerima sebagai hadiah dengana pengharapan akan memperoleh keuntungan, menjual, menyewakan, menggadaikan, mengangkat, menyimpan atau menyembunyikan suatu barang. Dari keterangan saksi-saksi serta keterangan terdakwa dalam persidangan, maka unsur ini telah terpenuhi. Yang mana terdakwa mendapatkan atau menerima gadai berupa satu unit mobil xenia.

c. Unsur yang diketahuinya atau yang patut harus diduga bahwa benda tersebut diperoleh dari kejahatan. Dari keterangan saksisaksi serta keterangan terdakwa dalam persidangan, unsur ini pula terpenuhi. Yang mana terdakwa mau menerima gadai 
berupa satu unit mobil xenia meskipun tanpa dilengkapi BPKB. ${ }^{32}$

3. Hal-hal yang memberatkan, antara lain :

a. Perbuatan terdakwa merugikan orang lain khususnya saksi korban Khumaidi.

b. Keadaan jiwa terdakwa yang mana terdakawa melakukan perbuatan tersebut secara sadar dan tanpa tekanan dari pihak manapun. ${ }^{33}$

4. Hal-hal yang meringankan, antara lain :

a. Terdakwa mengakui terus terang sehingga persidangan berjalan dengan lancar.

b. Terdakwa menyesali perbuatannya.

c. Terdakwa bersikap sopan selama persidangan.

d. Terdakwa belum pernah dihukum.

Berdasarkan pertimbangan-pertimbangan diatas maka menurut Majelis Hakim, semua unsur dalam dakwaan tunggal telah terbukti secara sah dan menyakinkan bahwa terdakwa telah melakukan tindak pidana, dan melanggar pasal 480 ayat 1 KUHP.

\section{Analisis Pertimbangan Hukum Hakim dalam Putusan No.293/Pid.B/2013/ Pengandilan Negeri Mojokerto tentang Tindak Pidana Penadahan dengan Sistem Gadai}

Memberikan deskripsi tentang pengertian hukum pidana tidaklah mudah. Sebab, suatu pengertian yang diberikan para ahli tentang pengertian hukum pidana akan berkaitan dengan cara pandang, batasan dan ruang lingkup dari pengertian tersebut. Maka, tidak mengherankan jika dijumpai banyak sekali pengertian hukum pidana yang dikemukakan oleh para ahli hukum pidana yang berbeda antara satu dengan yang lain.

Sebenarnya arti kata dari suatu istilah tidak begitu penting, karena yang lebih penting itu adalah pengertian suatu istilah. Pengertian suatu istilah inilah yang biasa digunakan untuk membedakan antara istilah yang satu dengan yang lainnya. ${ }^{34}$

Sesuai dengan sifatnya, sanksi pidana merupakan sanksi terberat atau paling keras dibandingkan dengan dengan jenis-jenis sanksi dalam

\footnotetext{
${ }^{32}$ Disalin dari Direktori Putusan Mahkamah Agung Republik Indonesia, 9.

${ }^{33}$ Wahyudi Said, Wawancara, Mojokerto, 3 Juni 2014.

${ }^{34}$ Wirjono Prodjodikoro, Asas-Asas Hukum Pidana di Indonesia, 1.
} 
berbagai bidang hukum yang lain. Fungsi hukum pidana dalam teori seringkali pula disebut sebagai fungsi subsidiaritas, yang artinya adalah penggunaan hukum pidana itu harus dilakukan secara hati-hati dan penuh dengan berbagai pertimbangan secara komprehensif. ${ }^{35}$

Para ahli hukum pidana memiliki pandangan yang berbeda mengenai tujuan hukum pidana, akan tetapi perbedaan tersebut mengarah pada kecenderungan yang sama. Yakni menyamakan antara tujuan hukum pidana dan tujuan penjatuhan pidana/pemidanaan. Tindak pidana penadahan merupakan suatu tindak pidana yang sering kali terjadi di kalangan masyarakat baik di pedesaan maupun diperkotaan. Tindak pidana penadahan merupakan salah satu tindakan yang sering dianggap remeh oleh masyarakat, karena ketidak tahuan masyarakat akan hukum sehingga mengakibatkan dampak negatif dilingkungan masyarakat.

Ketidak tahuan masyarakat akan hukum menjadikan tindak pidana ini sering kali terjadi. Tindak pidana penadahan ini mengakibatkan masyarakat menjadi resah.

Dalam menangani tindak pidana penadahan yang terjadi di Jalan Raya Cokroaminoto Kel. Balongsari Kec. Magersari Kota Mojokerto. Majelis hakim Pengadilan Negeri Mojokerto tidak serta merta dalam menjerat pelaku perbuatan ini. Akan tetapi dengan berbagai pertimbangan, yang telah dibuktikan dalam persidangan dan sesuai dengan dakwaan penuntut umum.

Dari hasil wawancara hakim dalam perkara tindak pidana penadahan pada Putusan No.293/Pid.B/2013/PN. Mojokerto ini, menyatakan antara lain:

a. Bahwasanya perbuatan terdakwa memenuhi unsur-unsur tindak pidana.

b. Bahwasanya perbuatan terdakwa memenuhi unsur-unsur dalam pasal 480 ayat 1.

c. Mengenai hal-hal yang memberatkan.

d. Mengenai hal-hal yang meringankan.

e. Bahwa perkara ini dakwaanya ada dalam tindak pidana penadahan.

f. Bahwa dalam persidangan Jaksa Penuntut Umum harus dapat membuktikan bahwa terdakwa benar-benar bersalah ${ }^{36}$

\footnotetext{
${ }^{35}$ Mahrus Ali, Dasar-Dasar Hukum Pidana, Ed. 1, Cet. 1 (Jakarta : Sinar Grafika, 2011), 11.

${ }^{36}$ Wahyudi Said, Wawancara, Mojokerto, 3 Juni 2014.
} 
Maka, dari hasil wawancara diatas dapat dianalisis sebagai berikut: salah satu pertimbangan yang digunakan oleh Majelis Hakim dalam tindak pidana ini adalah Pasal 480 ayat 1 KUHP. Selain Pasal 480 ayat 1 KUHP Majelis Hakim juga melihat hal-hal yang memberatkan dan halhal yang meringankan. Antara lain:

1. Pasal 480 ayat 1, yang menjelaskan barang siapa membeli, menawarkan, menukar, menerima gadai, menerima sebagai hadiah, atau untuk menarik keuntungan, menjual, menyewakan, menukarkan, menggadaikan, mengangkut, menyimpan, atau menyembunyikan suatu benda, yang diketahui atau sepatutnya harus diduga, bahwa diperoleh dari kejahatan. ${ }^{37}$

2. Hal-hal yang memberatkan, bahwa perbuatan terdakwa merugikan orang lain serta keadaan jiwa terdakwa yang secara sadar melakukan tindak pidana tersebut. ${ }^{38}$

3. Hal-hal yang meringankan, bahwa terdakwa mengakui secara terus terang dan menyesali perbuatannya. terdakwa bersikap sopan selama persidangan berjalan, serta terdakwa belum pernah dihukum. ${ }^{39}$

Sesuai dengan bukti-bukti dan saksi-saksi yang menyakinkan di depan persidangan, dapat dianalisis bahwasanya perbuatan terdakwa Suwono al-Lutung bin Giso menurut Ketua Majelis Pengadilan Negeri Mojokerto termasuk dalam kasus tindak pidana penadahan dengan sistem gadai. Dengan Putusan Nomor 293/Pid. B/ 2013/PN Mojokerto, sehingga Majelis Hakim secara menyakinkan menjatuhkan hukuman kepada terdakwa dengan Pasal 480 ayat 1 KUHP. Sesuai Pasal yang dijatuhkan kepada terdakwa Suwono, yakni dengan pidana penjara selama 6 (enam) bulan dengan dikurangi masa penahanan saat diadakannya pemeriksaan.

Meskipun dalam kasus ini, terdakwa merupakan korban yang pada awalnya tidak mengetahui bahwa barang yang digadaikan kepadanya adalah barang yang diperoleh dari hasil kejahatan. Dikarenakan minimnya pengetahuan akan hukum, menyebabkan terdakwa tidak mengetahui jika perbuatan yang dilakukannya tergolong tindak pidana yang ada dalam Pasal 480. Karena dalam perbuatan terdakwa terdapat delik kelalaian (culpa), terdakwa tetap saja di jerat

\footnotetext{
${ }^{37}$ Moeljatno, Kitab Undang-Undang Hukum Pidana,..., 172.

${ }^{38}$ Wahyudi Said, Wawancara..., 3 Juni 2014.

${ }^{39}$ Direktori Putusan Mahkamah Agung Republik Indonesia, Putusan No.293/Pid.B/2013/PN Mkt, 9.
} 
hukuman yang ada pada Pasal 480 ayat 1 KUHP meskipun terdakwa awalnya tidak menyadari akan perbuatan yang dilakukannya. Dalam kasus ini penulis sependapat atau setuju dengan hukuman yang diberikan oleh hakim kepada terdakwa, karena penulis juga berpendapat bahwa perbuatan yang dilakukan oleh terdakwa termasuk dalam tindak pidana penadahan, dengan bukti serta saksi yang ada dalam persidangan. Oleh karena tidak ada banding atau kasasi dari para pihak yang terkait dalam kasus tindak pidana penadahan dengan sistem gadai ini, artinya Putusan hakim dalam kasus ini bisa diterima para pihak, maka dapat dikatakan putusan tersebut telah adil.

\section{Analisis Fiqh Jinâyah terhadap Putusan No.293/pid.b/2013/ Pengadilan Negeri Mojokerto tentang Tindak Pidana Penadahan dengan Sistem Gadai}

Perbuatan manusia yang dinilai sebagai pelanggaran atau kejahatan kepada sesamanya, baik pelanggaran atau kejahatan secara fisik atau non fisik. Seperti membunuh, menuduh, atau memfitnah maupun kejahatan terhadap harta benda dan lainnya dibahas dalam Jinâyah. Fiqh Jinâyah merupakan bagian dari sharîah Islam yang berlaku semenjak diutusnya Rasulullah. Oleh karenanya pada zaman Rasululah dan Khulafaur Rasyidin, hukum pidana Islam berlaku sebagai hukum public, yaitu hukum yang diatur dan diterapkan oleh pemerintah selaku penguasa yang sah atau ulil amri.

Jarîmah, biasa dipakai sebagai perbuatan dosa, baik bentuk, macam ataupun sifatnya. Kata jarîmah identik dengan pengertian yang disebut dalam hukum positif sebagai tindak pidana atau pelanggaran. Adapun dalam pemakaiannya kata jinâyah lebih mempunyai arti lebih umum (luas), yakni ditujukan bagi segala sesuatu yang ada sangkut pautnya dengan kejahatan manusia dan tidak ditujukan bagi satuan perbuatan dosa tertentu. Oleh karena itu, pembahasan fiqh yang memuat masalah-masalah kejahatan dan pelanggaran yang dikerjakan manusia. Sedangkan hukuman yang diancamkan kepada pelaku perbuatan disebut fiqh jinâyah dan bukan istilah fiqh jarîmah. ${ }^{40}$

Hukum pidana (fiqh jinâyah) menurut sharî̀ah Islam merupakan bagian yang tak terpisahkan dalam kehidupan setiap muslim dimanapun ia berada. Sharî̀ah Islam merupakan hukum yang harus dilaksanakan

\footnotetext{
${ }^{40}$ Rahmat Hakim, Hukum Pidana Islam (Fiqh Jinayah)..., 11.
} 
oleh setiap muslim, karena sharîah Islam merupakan bagian dari ibadah kepada Allah swt. Dalam Fiqh jinâyah dijelaskan, bahwasanya barangsiapa mencuri atau mengambil harta milik orang lain tanpa izin dan berniat memiliki harta tersebut merupakan perbuatan yang melanggar sharî̉ah. ${ }^{41}$

Sesuai dengan ketentuan fiqh, larangan untuk melakukan atau tidak melakukan sesuatu tidaknya cukup dengan "niat baik", tetapi harus disertai sanksi (hukuman) yang diancamkan kepada yang melakukan kejahatan.

Ditinjau dari berat-ringannya hukuman yang diancamkan ada beberapa klasifikasi yang paling penting dan paling banyak dibahas para ahli hukum Islam mengenai kejahatan, yaitu:

a. Jarîmah hudûd, hudûd adalah bentuk jama' dari kata had yang asal artinya sesuatu yang membatasi di antara dua benda. Menurut bahasa, kata had berarti al-man' (cegahan). Adapun menurut shar'i, hudûd adalah hukuman-hukuman kejahatan yang telah ditetapkan oleh shara' untuk mencegah dari terjerumusnya seseorang kepada kejahatan yang sama. Kejahatan hudûd adalah kejahatan yang diancam dengan hukuman had yaitu hukuman yang ditentukan sebagai hak Allah. Kejahatan ini merupakan kejahatan yang paling berat dalam hukum pidana Islam. Hukum Pidana Islam tidaklah absolute, melainkan memberikan ruang gerak bagi akal fikiran manusia untuk berijtihad sehingga bisa merespon kebutuhan masyarakat secara dinamis. ${ }^{42}$

b. Jarîmah qisâs, yaitu jarîmah yang diancam dengan hukuman qisâs. Qisâs adalah hukuman yang sama dengan jarîmah yang dilakukan. Qisâs jatuh pada posisi di tengah antara kejahatan hudûd dan ta'zîr dalam hal beratnya. Sasaran dari kejahatan ini adalah integritas tubuh manusia, sengaja atau tidak sengaja. Ia terdiri dari apa yang dikenal dalam hukum pidana modern sebagai kejahatan terhadap manusia. Yang termasuk jarîmah ini ialah pembunuhan dengan sengaja dan penganiayaan dengan sengaja yang mengakibatkan terpotongnya atau terlukanya anggota badan. Pembunuhan menyerupai sengaja, pembunuh dengan sengaja, pembunuhan karena kealpaan,

\footnotetext{
${ }^{41}$ Sudarsono, Pokok-Pokok Hukum Islam..., 529.

${ }^{42}$ Sayyid Sabiq, Fikih Sunnah, 9 (Bandung: PT. al-Ma'arif, 1984), 213.
} 
penganiayaan, menimbulkan luka/ sakit karena kelalaian, masuk dalam kategori tindak pidana qisâs ini.

c. Jarîmah ta'zîr Adalah hukuman yang tidak dipastikan ketentuannya dalam nas (Al-Qur'an dan Sunnah Rasul). Jarîmah ta'zîr ada yang disebutkan dalam nas, tetapi macam hukumannya diserahkan kepada penguasa untuk menentukannya, dan ada jarîmah yang macam maupun hukumannya diserahkan sepenuhnya kepada penguasa. Landasan dan penentuan hukumnya didasarkan pada ijma'. Berkaitan dengan hak Negara untuk melakukan kriminalisasi dan menghukum semua perbuatan yang tidak pantas, yang menyebabkan kerugian/kerusakan fiisk, sosial, politik, finansial, atau moral bagi individu atau masyarakat secara keseluruhan.

Ta'zîr adalah hukuman yang bersifat mendidik atas perbuatan dosa yang belum ditetapkan oleh shara' atau hukuman yang diserahkan kepada keputusan hakim. Namun hukum ta'zîr juga dapat dikenakan atas kehendak masyarakat umum, meskipun bukan perbuatan maksiat, melainkan awalnya mubah.

Dasar hukum ta'zîr adalah pertimbangan kemaslahatan dengan mengacu pada prinsip keadilan. Pelaksanaannya pun bisa berbeda, tergantung pada tiap keadaan. Karena sifatnya yang mendidik, maka bisa dikenakan pada anak kecil. Sehingga, jarîmah ta'zîr berbeda dengan jarîmah hudûd.

Dari penjelasan macam-macam jarîmah di atas, dapat dikatakan bahwa tindak pidana penadahan yang dilakukan oleh terdakwa Suwono al Lutung Bin Giso dalam Islam merupakan pelanggaran syariat. Yang mana termasuk dalam jarîmah ta'zîr, Perbuatan yang dilakukan oleh terdakwa ini sama halnya dengan membantu atau memberi peluang kepada para pelaku untuk melakukan tindak pidana. Seperti dalam surat al-Ma'idah ayat: 2, yang berbunyi :

"Dan tolong menolonglah kamu sekalian dalam hal kebajikan dan ketakwaan, dan janganlah kamu tolong-menolong dalam dosa dan pelanggaran, dan bertakwalah kamu kepada Allah, sesungguhnya Allah amat berat siksanya". (al-M

Jelas sekali apa yang diterangkan dalam surat al-Maidah ayat 2, bahwasanya kita dilarang untuk tolong menolong dalam hal kejelekan atau batil. Adapun fungsi dan tujuan diterapkannya hukum bagi pelaku kejahatan, yakni mencapai kebahagiaan dunia akhirat. Sedangkan dari 
segi prioritas kepentingan bagi kehidupan masyarakat, maka tujuan serta fungsi diterapkannya hukum antara lain:

a. memelihara agama.

b. memelihara jiwa.

c. memelihara akal.

d. memelihara keturunan.

e. memelihara kehormatan.

f. serta memelihara harta. ${ }^{43}$

Para ahli Fiqh berpendapat, bahwasanya hukuman bagi orangorang yang melakukan kejahatan yang hukumannya tidak diatur dalam Al-Qur'an dan al-Sunnah yakni hukuman ta'zîr. Hukuman yang diberikan kepada pelaku bertujuan untuk memberikan peringatan atau pengajaran bagi pelaku jarîmah, supaya si pelaku menjadi jera dan tidak mengulangi perbuatannya kembali.

Sanksi ta'zîr dibedakan menjadi tiga yaitu:

a. Sanksi ta'zîr yang berkaitan dengan badan.

b. Sanksi ta'zîr yang berkaitan dengan kemerdekaan seseorang.

c. Dan saksi ta'zîr yang berkaitan dengan harta. ${ }^{44}$

Menurut pendapat penulis, bahwasanya tindak pidana penadahan dengan sistem gadai (Studi Putusan No.293/Pid.B/2013/PN.Mkt) yang dilakukan oleh terdakwa Suwono al Lutung, merupakan perbuatan yang melanggar Pasal 480 ayat 1 KUHP. Penulis pun berpendapat bahwa hukuman yang dijatuhkan kepada terdakwa sudah sesuai dengan perbuatan yang dilakukannya. Dalam hal ini selain berpegang pada Pasal 480 ayat 1 KUHP, Majelis hakim juga melihat dari hal-hal yang memberatkan, meringankan

serta keteragan dari para saksi sebagai landasan yang digunakan dalam memutus perkara ini. Sedangkan jika dilihat dari fiqh jinâyah, dapat dianalisis bahwa hukuman yang dijatuhkan kepada terdakwa yakni penjara selama 6 bulan sudah sesuai dengan surat al-Baqarah ayat 178 tentang pemaafan, yang berbunyi :

"yang demikian itu adalah keringanan dan rahmat dari tuhanmu". 45

\footnotetext{
${ }^{43}$ Quraish Shihab, Tafsir Al-Misbah, 9.

${ }^{44}$ Nurul Irfan, Masyrofah, Figh Jinayah..., 149.

${ }^{45}$ Departemen Agama RI, al-Qur'an dan Terjemahannya (Jakarta Timur: Pustaka al-Kautsar, 2011), 27.
} 
Hukuman ini sudah sesuai menurut Islam karena hakim memberikan keringanan hukuman kepada terdakwa dengan member pemaafan serta melihat fakta-fakta yang ada dalam persidangan. Dan tindak pidana ini merupakan tindak pidana yang dijatuhi hukuman ta'zîr. Dalam kasus ini dapat dianalisis bahwa hukuman pidana selama 6 bulan yang dijatuhkan oleh hakim menurut hukum pidana Islam telah sesuai Yang mana hukuman ta'zîr merupakan hukuman yang seluruhnya diserahkan kepada ulil amri atau hakim.

Dalam kasus tindak pidana penadahan dengan sistem gadai ini, penulis tidak mempersalahkan akan sistem yang digunakan penadah. Karena pada dasarnya Islam memperbolehkan gadai atau rahn sesuai dengan hadis Nabi:

"Dari Anas RA. berkata, Rasulullah saw pernah menggadaikan baju besinya kepada seorang yahudi di Madinah, dan darinya beliau telah mengambil gandum untuk keluarganya". ${ }^{46}$

Akan tetapi, jika gadai $(r a h n)$ ini digunakan atau diperoleh dari hasil kejahatan, maka Islam melarangnya. Seperti dalam kasus No.293/Pid.B/2013/PN. Mkt Islam melarang hal ini, karena perbuatan dalam kasus tersebut dapat meresahkan masyarakat.

\section{Simpulan}

Bahwasanya dalam memutus perkara penadahan pada Putusan No.293/Pid.B/2013/Pengadilan Negeri Mojokerto, Majelis Hakim menggunakan banyak pertimbangan serta landasan hukum. Diantara pertimbangan yang digunakan adalah : Pasal 480 ayat 1 KUHP, hal-hal yang memberatkan, serta hal-hal yang meringankan.

Maka, Majelis Hakim Pengadilan Negeri Mojokerto menjatuhkan kepada terdakwa Suwono al Lutung dengan hukuman pidana penjara selama 6 (enam) bulan dengan dikurangi masa tahanan.

Sedangkan dalam tinjauan Fiqh Jinâyah terhadap Putusan Pengadilan Negeri Mojokerto No. 293/Pid.B/2013 yang dilakukan oleh terdakwa Suwono al Lutung Bin Giso yakni, sesuai dengan hukuman yang mana hukuman atau sanksinya tidak ada dalam nas.

\footnotetext{
${ }^{46}$ Sayyid Sabiq, Fikih Sunnah, 12 (Bandung: Pustaka, 1988), 140.
} 


\section{Daftar Rujukan}

Ali, Makhrus. Dasar-Dasar Hukum Pidana, Cet. 1. Jakarta: Sinar Grafika, 2011.

Ali, Zainuddin. Hukum Pidana Islam. Jakarta: Sinar Grafika, 2012.

Al-Mawardi. Hukum-Hukum Penyelenggaraan Negara dalam Syariat Islam. Jakarta: Darul-Falah, 2012.

Ash-Shiddieqy, Hasbi. Hukum-Hukum Fiqh Islam. Jakarta: Bulan Bintang, 1970.

Audah, Abd al-Qadir. al-Tasyri' al-Jinaiy al-Islamiy. Dar al-Kitab alArabi.

Bambang, Sungkono. Metodologi Penelitian Hukum. Jakarta: PT. Raja Grafindo Persada, 1997.

Djazuli, Ahmad. Fiqh Jinâyah. Jakarta: PT. Grafindo Persada, 1992.

Enny, RA Manurung. Wawancara. Pengadilan Negeri Mojokerto, 3 Juni 2014.

Fattah Idris, Abdul. Kifayatul Akhyar Terjemahan Ringkasan Fiqh Islam. t.tp., t.p., t.t.

Hakim, Rahmat. Hukum Pidana Islam (Fiqh Jinâyah). Bandung: Pustaka Setia, 2000.

Hamzah, Andi. Delik-delik tertentu di dalam KUHP. Jakarta: Sinar Grafika, 2009.

Haroen, Nasrun. Fiqh Muamalah. Jakarta: Gaya Media Pratama, 2000.

Lamintang. Delik-Delik Khusus Kejahatan Terhadap Harta Kekayaan. Jakarta: Sinar Grafika, 2009.

Moeljatno. Kitab Undang-Undang Hukum Pidana. Jakarta: Bumi Aksara, 2012.

Munajat, Makhrus. Dekonstruksi Hukum Pidana Islam. Jogyakarta: Logung Pustaka, 2004.

Muslich, Ahmad Wardi. Hukum Pidana Islam. Jakarta: Sinar Grafika, 2005.

Prodjodikoro, Wirjono. Tindak-Tindak Pidana Tertentu di Indonesia. Bandung: PT. Rifeka Aditama, 2010.

Projodikoro, Wirjono. Asas-Asas Hukum Pidana di Indonesia, Cet. 2. Bandung: Eresco, 1989. 
Rawas Qal'ahji, Muhammad. Ensiklopedi Fiqh. Jakarta: Raja Grafindo Persada, 1999.

Sabiq, Sayyid. Fiqh Sunnah, Juz 3. Bandung: PT. Al-Ma’arif, 1987.

-------. Fiqh Sunnah, Juz 10. Bandung: PT. Ma'arif, t.t.

Said, Wahyudi. Wawancara. Pengadilan Negeri Mojokerto, 3 Juni 2014.

Shihab, M. Quraish. Al-Qur'an dan Maknanya. Tangerang: Lentera Hati, 2010.

Shihab, M. Quraish. Tafsir al-Misbah, Vol. 3. Ciputat: Lentera Hati, 2001.

Simorangkir et al. Kamus Hukum. Jakarta: Sinar Grafika, 2000.

Sudarsono. Kamus Hukum. Jakarta: Rineka Cipta, 1992.

Pokok-Pokok Hukum Islam. Jakarta: Rineka Cipta, 1992.

Syafe'i, Rahmat. Fiqh Muamalah. cet. 1, Bandung: Pustaka Setia, 2006.

Syarifuddin, Amir. Garis-Garis Besar Fiqh. Jakarta: Kencana, 2003. 